\title{
ОРГАНІЗАЦІЯ НАВЧАЛЬНОГО ПРОЦЕСУ У ВИЩИХ НАВЧАЛЬНИХ ЗАКЛАДАХ МІНІСТЕРСТВА ОХОРОНИ ЗДОРОВ'Я УКРАЇНИ В УМОВАХ ВПРОВАДЖЕННЯ ЗАКОНУ УКРАЇНИ “ПРО ВИЩУ ОСВІТУ” (ЗА ПІДСУМКАМИ МОНІТОРИНГУ В 2016 р.)
}

\author{
Ю. С. П’ятницький ${ }^{1}$, І. В. Мельник ${ }^{2}$, М. О. Поліщук ${ }^{2}$, Ю. І. Фисун
}

${ }^{1}$ Міністерство охорони здоров'я України,

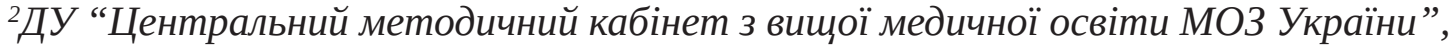

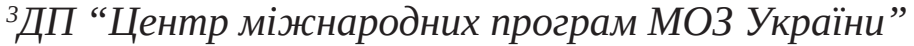

\section{ORGANIZATION OF EDUCATIONAL PROCESS AT HIGHER EDUCATIONAL ESTABLISHMENTS OF MINISTRY OF HEALTH OF UKRAINE IN TIME OF IMPLEMENTATION OF THE LAW OF UKRAINE “ON HIGHER EDUCATION” (RESULTS OF MONITORING IN 2016)}

Yu. S. Pyatnytskyi', I. V. Melnyk², M. O. Polishchuk ${ }^{2,}$ Yu. I. Fysun ${ }^{3}$

${ }^{1}$ The Ministry of Health of Ukraine,

${ }^{2} S I$ "Central methodical cabinet of higher medical education the Ministry of Health of Ukraine", ${ }^{3} \mathrm{SE}$ “Center for International Programs Ministry of Health of Ukraine"

\footnotetext{
У статті наведено результати моніторингу стану організації навчального процесу у вищих медичних та фармацевтичних навчальних закладах і закладах післядипломної освіти, підпорядкованих МОЗ України, в 2016 р.

The article presents the results of monitoring the state of the educational process in higher medical and pharmaceutical education and postgraduate educational institutions subordinated to the Ministry of Health of Ukraine in 2016.
}

Вступ. Міністерство охорони здоров’я України з метою забезпечення реалізації пункту 5 частини другої статті 13 Закону України від 01.07.2014 р. № 1556-VII “Про вищу освіту” (далі - Закон України “Про вищу освіту”) [1], відповідно до якого державні органи, до сфери управління яких належать вищі навчальні заклади, аналізують якість освітньої діяльності вищих навчальних закладів, що належать до сфери їх управління, та відповідно до наказу МОЗ України від 24.10.2012 р. № 834 “Про навчально-методичну діяльність вищих медичних та фармацевтичних навчальних закладів I-IV рівнів акредитації”, у 2016 р. продовжило моніторинг стану організації навчального процесу у вищих медичних та фармацевтичних навчальних закладах і закладах післядипломної освіти, підпорядкованих МО3 України (далі ВНЗ МОЗ України). Міністр охорони здоров’я
України О. Квіташвілі затвердив Графік моніторингу навчально-методичної діяльності вищих медичних та фармацевтичних навчальних закладів та закладів післядипломної освіти, підпорядкованих МО3 України, на 2016 р. Протягом першого півріччя 2016 р. було здійснено оцінку стану навчально-методичної роботи в Запорізькому державному медичному університеті (далі - ЗДМУ), ДЗ “Запорізька медична академія післядипломної освіти МОЗ України” (далі-ЗМАПО), Харківській медичній академії післядипломної освіти (далі - ХМАПО), Національному фармацевтичному університеті (далі - НФаУ) та ДВНЗ “Івано-Франківський національний медичний університет” (далі - ІФНМУ).

Основна частина. Зазначений захід здійснюється з урахуванням реалізації статті 16 розділу V Закону України “Про вищу освіту”, згідно з якою

() Ю. С. П’ятницький, І. В. Мельник, М. О. Поліщук, Ю. І. Фисун 
система забезпечення якості вищої освіти в Україні складається із:

1) системи забезпечення вищими навчальними закладами якості освітньої діяльності та якості вищої освіти (система внутрішнього забезпечення якості);

2) системи зовнішнього забезпечення якості освітньої діяльності вищих навчальних закладів та якості вищої освіти;

3) системи забезпечення якості Національного агентства із забезпечення якості вищої освіти і незалежних установ оцінювання та забезпечення якості вищої освіти [1].

Слід також додати, що проблемі забезпечення якості навчання і викладання було присвячено Конференцію міністрів освіти Європейського простору вищої освіти і четвертий Болонський політичний форум в Єревані 14-15 травня 2015 р. [3].

У Стандартах і рекомендаціях щодо забезпечення якості в Європейському просторі вищої освіти (ESG) (далі - Стандарти), ухвалених Міністерською конференцією в Єревані, зазначено, що Стандарти щодо забезпечення якості поділяються на три частини: внутрішнє забезпечення якості, зовнішнє забезпечення якості, забезпечення якості відповідними агентствами.

Ці Стандарти мають використовуватись закладами та агентствами забезпечення якості як рекомендаційний документ для зовнішніх і внутрішніх систем забезпечення якості у вищій освіті.

За підсумками моніторингу, проведеного у вищих медичних та фармацевтичних навчальних закладах і закладах післядипломної освіти, підпорядкованих МОЗ України, у 2016 р. (далі - моніторинг) підготовлено довідки, в яких зазначено стан виконання пропозицій МО3 України щодо усунення зауважень та недоліків, виявлених під час попереднього моніторингу навчально-методичної діяльності даного навчального закладу, пропозиції моніторингової групи з метою подальшого вдосконалення навчально-методичної роботи у ньому, доцільність розповсюдження позитивного досвіду серед інших ВНЗ МОЗ України.

Моніторинг здійснювався 3 метою вивчення особливостей та рівня навчально-методичної діяльності ВНЗ МОЗ України відповідно до розробленого МОЗ України переліку питань, які підлягають моніторингу, що включав розділи: загальні питання; стан виконання пропозицій МОЗ України щодо усунення зауважень та недоліків, виявлених під час попереднього моніторингу навчальнометодичної діяльності ВНЗ МОЗ України; реалізація нормативно-правових актів і доручень МОЗ України щодо покращення якості та організації підготовки лікарів; розвиток інфраструктури ВНЗ MO3 України; кадровий склад (кількісні та якісні показники, підвищення педагогічної та лікарської кваліфікації науково-педагогічних працівників); контингент осіб, що навчаються (вітчизняні та іноземні громадяни); результати державної атестації студентів та інтернів (практично-орієнтовані іспити, “Крок”); організація роботи центрів практичної підготовки студентів (лікарів-інтернів, слухачів закладів післядипломної освіти), їх оснащення; загальна організація навчально-методичного процесу; організація і навчально-методичне забезпечення післядипломної підготовки лікарів (у тому числі дистанційне навчання); підготовка навчальнометодичної літератури, видавнича діяльність; забезпеченість навчальною книгою; інформатизація навчального процесу (новітні технології та засоби навчання, дистанційна освіта); міжнародна діяльність; внутрішній рейтинг і система управління якістю; науково-винахідницька діяльність та питання трансферу технологій. При цьому було зроблено акцент на впровадженні положень Закону України “Про вищу освіту”, зокрема оновленні статутів навчальних закладів, положень та наказів, що регламентують управління навчальним процесом.

Метою моніторингу є вивчення якості підготовки медиків і фармацевтів, стану та особливостей навчально-методичної діяльності навчальних закладів з урахуванням наявних ліцензованих спеціальностей, обсягів, напрямів та специфіки підготовки в умовах впровадження Закону України “Про вищу освіту” [2].

Моніторингові групи були сформовані таким чином, що включали представників різних навчальних закладів (проректори з навчальної роботи, декани, завідувачі науково-методичної лабораторії з питань фармацевтичної освіти та проблемної науково-дослідної лабораторії з питань післядипломної підготовки лікарів/провізорів) та представників структурних підрозділів MO3 України. Це сприяло обговоренню проблем організації навчального процесу у ВН3 МОЗ України в умовах впровадження основних положень Закону України “Про вищу освіту” через призму тих завдань і проблем їх вирішення, які виникали і в закладах, де працюють члени моніторингових груп. 
Загалом результати проведеного моніторингу свідчать про те, що більшість зауважень, внесених у 2013-2015 рр., ліквідована.

Разом 3 тим:

- недостатніми залишаються рівень публікацій співробітників ВНЗ МОЗ України у виданнях бази Scopus, кількість підготовлених патентів на винаходи та інформаційних листів за результатами виконаних наукових досліджень;

- неповною мірою реалізований план заходів щодо забезпечення належної організації навчального процесу з метою поліпшення результатів складання ліцензійних іспитів “Крок”;

- недостатнім є забезпечення студентів оновленою навчальною книгою.

Одним із першочергових завдань щодо імплементації Закону України “Про вищу освіту”, визначеним у пункті 7 розділу XV “Прикінцеві та перехідні положення” Закону України “Про вищу освіту” та у відповідних дорученнях Міністерства освіти і науки України, було оновлення статутів навчальних закладів. У всіх ВНЗ МОЗ України, де здійснювався моніторинг, підготовлено оновлені статути навчальних закладів, які затверджено в установленому порядку (в ЗМАПО - знаходиться на затвердженні у MO3 України). Разом з тим, уже є потреба внести зміни до Статуту ХМАПО (затверджений наказом МО3 України від 03.10.2014 р. № 701), передбачивши у ньому функціонування таких структурних підрозділів, як Навчально-науковий інститут стоматології та відділ з охорони праці. 3 урахуванням нових редакцій статутів університетів (академій) назріла необхідність оновлення концепцій розвитку навчальних закладів (наприклад, в ІФНМУ, ЗМАПО).

Другим із першочергових завдань був перехід на обсяг одного кредиту ЄКТС як одиниці вимірювання обсягу навчального навантаження здобувача вищої освіти, необхідного для досягнення визначених (очікуваних) результатів навчання.

У всіх навчальних закладах навчальні плани додипломної підготовки фахівців за всіма спеціальностями побудовані з урахуванням обсягу одного кредиту EKTC (30 год) на виконання вимог статті 1 “Основні терміни та їх визначення” розділу I “Загальні положення” Закону України “Про вищу освіту”.

На виконання вимог абзацу третього частини другої статті 56 та частини сьомої розділу XV “Прикінцеві та перехідні положення” Закону України
“Про вищу освіту” в навчальних закладах впроваджувались скореговані навчальні плани додипломної підготовки фахівців за всіма спеціальностями. При цьому у НФаУ та ІФНМУ перехід на 600 год навчального навантаження на одну ставку науково-педагогічного працівника на навчальний рік здійснено одночасно на всіх курсах навчання. У ЗДМУ, ЗМАПО, ХМАПО, за рішенням вчених рад, цей перехід здійснюється поступово, починаючи $з$ першого курсу, на підставі листів-дозволів МОН України від 04.03.2015 р. № 1/11-2996 до ДУ “Центральний методичний кабінет з вищої медичної освіти МОЗ України” та до вищих навчальних закладів від 13.03.2015 р. № 1/9-126.

У всіх навчальних закладах здійснюються заходи з метою приведення штатного розпису у відповідність зі статтею 55 “Основні посади наукових, науково-педагогічних і педагогічних працівників вищих навчальних закладів та порядок їх заміщення” Закону України “Про вищу освіту” та пункту 6 статті 35 “Керівник факультету, навчальнонаукового інституту, кафедри”. Однак не у всіх навчальних закладах цей процес завершено у повному обсязі. Є потреба у всіх ВНЗ України у подальшому формуванні дієвого резерву на посади завідувачів кафедр з числа докторів наук шляхом активізації роботи із захисту докторських дисертацій; вжитті заходів щодо збільшення кількості викладачів, які мають науковий ступінь та наукове звання, активізації роботи з підготовки науково-педагогічних кадрів на непрофільних кафедрах (наприклад, у НФаУ, ЗМАПО, ХМАПО). Ректорам навчальних закладів слід забезпечити можливість підготовки здобувачів та науково-педагогічних працівників 3 формування мовних компетенцій на рівні В2 згідно з вимогами МОН України та Загальноєвропейських рекомендацій з мовної освіти. Відділам кадрів необхідно своєчасно вносити інформацію щодо проходження підвищення кваліфікації науково-педагогічними працівниками. У зв’язку 3 оновленням адміністративного складу навчальних закладів, у тому числі з урахуванням кадрових змін, пов’язаних з імплементацією Закону України “Про вищу освіту”, було рекомендовано вжити заходів для забезпечення обміну досвідом роботи між співробітниками навчального закладу та іншими ВНЗ МОЗ України.

Згідно із статтею 47 розділу IX “Організація освітнього процесу” Закону України “Про вищу освіту” та відповідними дорученнями МОН Украї- 
ни, вищі навчальні заклади мали розробити і затвердити рішенням вченої ради положення про організацію навчального процесу. Зважаючи на те, що наказом МОН України від 13.11.2014 р. № 1310 ліквідовано наказ МОН України № 161 “Про затвердження Положення про організацію навчального процесу у вищих навчальних закладах”, який регламентував усі основні аспекти організації навчального процесу, такі положення мають бути дієвими і не містити формальної інформації. Як свідчать підсумки моніторингу, проведеного у 2016 р., положення про організацію освітнього (навчального) процесу розроблено у всіх навчальних закладах. Разом $з$ тим, практично у всіх навчальних закладах, де здійснювався моніторинг, є потреба в їх доопрацюванні з урахуванням оновленої нормативної бази. Зокрема, зустрічаються посилання на наказ МОН України від 02.06.1993 р. № 161, який втратив чинність, разом з тим, не зазначено Інструкцію щодо оцінювання навчальної діяльності студентів в умовах впровадження Європейської кредитнотрансферної системи організації навчального процесу (затверджена заступником міністра охорони здоров’я та надіслана для впровадження з листом MO3 України від 15.04.2014 р. № 08.01-47/10395) (наприклад, у НФаУ, ЗДМУ, ІФНМУ).

Як свідчать підсумки моніторингу, проведеного у 2016 р., $є$ потреба у внесенні доповнень до положення про кафедру університету (академії) вимогами до підготовки та ведення навчально-методичної документації (ЗДМУ, ЗМАПО, ХМАПО, НФаУ, ІФНМУ), а також посиленні контролю з боку завідувачів кафедр за веденням кафедральної документації, зокрема оновленням методичних рекомендацій для студентів, особливо для організації самостійної роботи.

Ураховуючи зростання ролі вчених рад в організації освітньої діяльності навчальних закладів, є доцільним внесення доповнень до положень про вчені ради та приведення їх у відповідність із Законом України “Про вищу освіту”. Не у всіх навчальних закладах утворено наглядову раду для здійснення нагляду за управлінням майном вищого навчального закладу на виконання статті 37 Закону України від 01.07.2014 р. № 1556-VII “Про вищу освіту” (наприклад, у ХМАПО).

Обговорення зазначених положень у навчальних закладах спільно із членами моніторингових груп свідчить про доцільність створення методичних рекомендацій щодо розробки положень про орга- нізацію навчального процесу у ВНЗ МОЗ України та форм документів з урахуванням підсумків моніторингу й обговорення на нараді відповідних фахівців ВНЗ МОЗ України.

Ураховуючи динаміку оновлення нормативноправових документів, що регламентує організацію освітньої діяльності навчальних закладів загалом, $є$ потреба у внесенні до посадових інструкцій керівників структурних підрозділів вимоги щодо проведення моніторингу нормативно-правової бази в межах посадових повноважень. Зокрема, невчасно внесені зміни до положень про дистанційне навчання з урахуванням вимог наказу $\mathrm{MOH}$ України від 14.07.2015 р. № 761 “Про затвердження змін до Положення про дистанційне навчання” та положень про академічну мобільність наукових і науково-педагогічних працівників та осіб, які навчаються, згідно з вимогами Постанови Кабінету Міністрів України від 12.08.2015 р. № 579 “Про затвердження Положення про порядок реалізації права на академічну мобільність” (наприклад, у ХМАПО). Містить посилання на нормативні документи, які втратили чинність, положення про систему оцінювання навчальної діяльності студентів при кредитно-модульній системі організації навчального процесу в ЗДМУ.

Загалом необхідно зауважити, що в більшості навчальних закладів є потреба у системному оновленні діючих положень про структурні й функціональні підрозділи та посадових інструкцій співробітників з урахуванням затвердженого в установленому порядку статуту університету (академії) та затвердженні їх відповідними наказами, а також у посиленні внутрішнього контролю за виконанням рішень вченої ради, організацією підготовки нормативних актів, службових документів, інструкції $з$ діловодства, а також контролю деканів та завідувачів кафедр за веденням індивідуальних планів роботи викладачів, планів та звітів про роботу кафедр, а також у посиленні контролю з боку профільних служб навчальних закладів щодо виконання наказів та доручень МО3 України.

Особливу увагу члени моніторингових груп приділили ознайомленню з розробленими у навчальних закладах положеннями про планування та облік науково-педагогічної діяльності з урахуванням вимог Закону України “Про вищу освіту”.

Зазначені положення розроблялись з урахуванням наказу МОН України від 07.08.2002 р. № 450 “Про затвердження норм часу для планування і об- 
ліку навчальної роботи та переліків основних видів методичної, наукової й організаційної роботи педагогічних, науково-педагогічних працівників вищих навчальних закладів”, зареєстрованого в Міністерстві юстиції України 21.09.2002 р. за № 698/6986, в якому норми часу вказані тільки для планування і обліку навчальної роботи - усього 31 позиція.

Разом з тим, у більшості навчальних закладів рішеннями вчених рад затверджено і години для обліку наукової та методичної діяльності. Обсяги цих годин є різними у всіх навчальних закладах.

Як свідчать підсумки обговорення зазначеного питання під час проведення моніторингу у навчальних закладах, є потреба в опрацюванні 3 представниками всіх навчальних закладів методик (показників) для планування обліку наукової і методичної роботи науково-педагогічних працівників та підготовці відповідних рекомендацій.

Під час здійснення моніторингу особливу увагу було приділено наявності у навчальних закладах ефективної системи забезпечення вищим навчальним закладом якості освітньої діяльності та якості вищої освіти (система внутрішнього забезпечення якості) на виконання вимог статті 16 “Система забезпечення якості вищої освіти” розділу V “Забезпечення якості вищої освіти” Закону України “Про вищу освіту”. Члени моніторингових груп зробили наголос на необхідності удосконалення діяльності відділів (секторів) моніторингу якості освіти з розробки дієвих пропозицій до керівників навчальних закладів для забезпечення прийняття адміністраціями вчасних управлінських рішень щодо удосконалення якості освітнього процесу, не обмежуватись проведенням і аналізом результатів анкетування і соціологічних досліджень. Рекомендовано деканатам факультетів, відділам (секторам) моніторингу якості освіти навчальних закладів спільно з органами студентського самоврядування упродовж навчального року забезпечувати дієвий зворотний зв’язок з учасниками навчального процесу та підготовку пропозицій щодо прийняття необхідних управлінських рішень.

Постановою Кабінету Міністрів України від 30.12.2015 р. № 1187 затверджені Ліцензійні умови провадження освітньої діяльності закладів освіти (далі - Ліцензійні умови). Розділ “Технологічні вимоги щодо навчально-методичного забезпечення провадження освітньої діяльності у сфері вищої освіти” (додаток 14 до Ліцензійних умов) містить показник забезпеченості студентів навчальними матеріалами 3 кожної навчальної дисципліни навчального плану. При цьому “...забезпеченістю навчальними матеріалами вважається наявність підручників, навчальних посібників, конспектів лекцій, хрестоматій згідно з переліком рекомендованої літератури з розрахунку: один примірник на п’ять осіб фактичного контингенту студентів та заявленого додаткового ліцензованого обсягу в разі розширення провадження освітньої діяльності...".

Як свідчать результати моніторингу, враховуючи низькі показники забезпечення здобувачів вищої освіти сучасною навчально-методичною літературою за даними бібліотек навчальних закладів, потребує активізації у всіх навчальних закладах робота авторських колективів із написання підручників і посібників для отримання рекомендацій MO3 України відповідно до наказу МОЗ України від 19 січня 2015 р. № 20 “Про організацію підготовки навчальної та навчально-методичної літератури”. Є потреба у внесенні змін (доповнень) до відповідних положень про порядок підготовки та експертизи навчальних і навчально-методичних засобів навчання, розроблених у ВНЗ МОЗ України та затверджених вченими радами навчальних закладів.

Слід зауважити, що при розробці зазначених рекомендацій не у всіх навчальних закладах були враховані методичні рекомендації “Підготовка електронних видань, дидактичних демонстраційних матеріалів, електронних навчальних посібників та підручників у вищих медичних навчальних закладах”, затверджені МОЗ України 17.09.2015 р. та надіслані до ВНЗ МОЗ України для впровадження 3 листом від 18.09.2015 р. № 23-01-9/443, а також методичні рекомендації “Підготовка електронних навчальних матеріалів (електронних підручників та навчальних посібників) до видання”, розроблені фахівцями Національної медичної академії післядипломної освіти імені П. Л. Шупика спільно з МОЗ України та ЦМК (лист МОЗ України від 27.10.2015 р. № 08.01-47/34048).

Члени моніторингових груп зробили також наголос на необхідності розробки положення про запобігання випадкам академічного плагіату з урахуванням вимог статті 32 розділу VI “Вищі навчальні заклади” Закону України “Про вищу освіту”, а саме: “...вищі навчальні заклади зобов’ язані вживати заходів, у тому числі шляхом запровадження відповідних новітніх технологій 
щодо запобігання та виявлення академічного плагіату в наукових роботах наукових, науковопедагогічних, педагогічних, інших працівників і здобувачів вищої освіти та притягнення їх до дисциплінарної відповідальності”. Алгоритми проведення експертизи на плагіат мають бути затверджені рішенням вченої ради (наприклад, у ЗМАПО). Майже у всіх навчальних закладах, де таке положення розроблено, не враховано доручення МОЗ України від 16.12.2014 р. № 08.0147/36675 щодо необхідності затвердження на вче- них радах положення про запобігання випадкам академічного плагіату.

У 2015 р. найбільша кількість рукописів, які отримали відповідні рекомендації МОЗ України щодо їх видання згідно з рішенням Комісії для організації підготовки навчальної та навчально-методичної літератури для осіб, які навчаються у вищих медичних (фармацевтичному) навчальних закладах та закладах післядипломної освіти МОЗ України, визначеної у наказі МОЗ України від 19.01.2015 р. № 20, підготовлена у ЗДМУ (табл.).

Таблиця. Кількість рукописів, які отримали у 2015 р. рекомендації МОЗ України щодо їх видання

\begin{tabular}{|l|c|c|c|c|c|}
\hline \multicolumn{1}{|c|}{ ВНЗ } & ЗДМУ & ІФНМУ & НФаУ & ЗМАПО & ХМАПО \\
\hline Кількість підручників & 1 & & & & 1 \\
\hline Кількість посібників & 15 & 4 & 2 & 2 & 2 \\
\hline Всього: & 16 & 4 & 2 & 2 & 3 \\
\hline
\end{tabular}

Зважаючи на необхідність навчально-методичного забезпечення викладання блоків військовомедичної тематики відповідно до програм додипломної та післядипломної підготовки у вищих навчальних закладах МОЗ України на виконання відповідних доручень МОЗ України, зокрема Плану заходів МОЗ України для організації навчального процесу у вищих медичних та фармацевтичних навчальних закладах та закладах післядипломної освіти, підпорядкованих МОЗ України, в умовах режимів підвищеної готовності та надзвичайних ситуацій відповідно до листа МО3 України від 10.03.2015 р. № 08.01-47/7130, керівникам навчальних закладів рекомендовано здійснювати першочергово закупівлю навчально-методичної літератури з питань військово-медичної тематики з переліку видань, підготовлених за участі (співавторство, рецензування) фахівців Української військово-медичної академії.

Ураховуючи підсумки складання інтегрованих ліцензійних іспитів “Крок” здобувачами вищої освіти у вищих медичних (фармацевтичному) навчальних закладах, в усіх навчальних закладах, де проведено моніторинг у 2016 р., члени моніторингових груп рекомендували розробити та затвердити на засіданнях вчених рад плани заходів щодо забезпечення належної організації навчального процесу з метою поліпшення результатів складання ліцензійних іспитів “Крок”, посилити роль деканатів та відділів інтернатури і відповідальність завідувачів кафедр у підготовці здобувачів вищої освіти до складання іспиту, активізувати роботу науково-педагогічних працівників кафедр щодо підготовки методичних розробок до самостійної роботи студентів та слухачів.

Для належного забезпечення процесу оволодіння здобувачами вищої освіти практичними навичками та методиками моніторинговими групами рекомендовано продовжити створення тренінгових центрів для забезпечення практичної підготовки здобувачів вищої освіти, оснащення кафедр устаткуванням для моделювання невідкладних станів та відпрацювання практичних навичок з надання медичної допомоги при них.

Члени моніторингових груп, ознайомившись із станом реалізації статті 67 розділу XI “Наукова, науково-технічна та інноваційна діяльність у вищих навчальних закладах" Закону України “Про вищу освіту”, рекомендували керівникам ВНЗ MO3 України активізувати залучення науковопедагогічних працівників навчальних закладів до участі в міжнародних освітніх та наукових програмах, які підтримані відповідними грантами, зокрема, продовжити роботу з пошуку партнерів для реалізації наявних проектів з європейським партнерством у рамках програми “Горизонт-2020”, Європейських програм стажування та академічного обміну (Erasmus+, Horizont 2020 та інших); інтенсифікувати роботу щодо виконання спільних наукових досліджень науково-дослідними інститутами та вищими медичними навчальними закладами України і зарубіжних країн, збільшення кількості наукових форумів з актуальних проблем та досягнень $з$ різних напрямів сучасної медичної науки 
і практики. Рекомендовано також продовжити діяльність щодо набуття членства у профільних міжнародних асоціаціях та організаціях; вжити заходів щодо поліпшення якості презентацій наукових досліджень викладачів та здобувачів у провідних фахових виданнях з імпакт-фактором у наукометричній базі даних Scopus.

3 метою збільшення контингенту іноземних здобувачів вищої освіти у навчальних закладах рекомендовано посилити міжнародну профорієнтаційну діяльність з розширення “географії” країн набору, поглибити взаємодію з ДП “Центр міжнародних програм МОЗ України” щодо участі у галузевих програмах міжнародного співробітництва, витримувати норми контролю стосовно встановлених законодавством України термінів тривалості щорічних відпусток клінічних ординаторів з числа іноземних громадян.

Підсумовуючи, слід зазначити, що результати проведеного у першому півріччі 2016 р. моніторингу навчально-методичної діяльності вищих медичних (фармацевтичного) навчальних закладів та закладів післядипломної освіти, підпорядкованих MO3 України, свідчать, що у ВНЗ МОЗ України вживаються заходи для належного впровадження положень Закону України “Про вищу освіту”. Пропозиції щодо подальшого удосконалення організа-

\section{Список літератури}

1. Про вищу освіту : Закон України від 01.07.2014 р. № 1556-VII.

2. Моніторинг як важлива складова покращення якості освіти / М. С. Осійчук, О. П. Волосовець, Ю. С. П’ятницький [та ін.] // Досягнення і перспективи впровадження кредитно-модульної системи організації навчального процесу у вищих медичних (фармацевтичному) навчальних закладах України : матеріали Всеукр. навч.-наук. конф. з міжнар. участю. - Тернопіль : ТДМУ, 2014. - C. 14-18. ції навчально-методичної роботи, висловлені у процесі моніторингу у переважній більшості ВН3 МО3 України, можуть бути реалізовані у найближчі терміни. Разом з тим, у процесі обговорення окреслена необхідність подальшого опрацювання спільно 3 відповідними фахівцями навчальних закладів рекомендацій щодо підготовки положень про організацію освітнього процесу у ВНЗ МОЗ України, про кафедру ВНЗ МОЗ України, нормування часу у ВНЗ MO3 України та інших. На думку членів моніторингових груп, цю роботу доцільніше буде здійснювати після реалізації Графіка моніторингу навчальнометодичної діяльності вищих медичних та фармацевтичних навчальних закладів та закладів післядипломної освіти, підпорядкованих МОЗ України, на 2016 p.

Висновок. Проведення моніторингу організації освітньої діяльності у ВНЗ МОЗ України за участі представників усіх навчальних закладів у якості членів моніторингових груп сприятиме “...вибудовуванню горизонтальних експертних мереж для пошуку ефективних рішень та забезпечення професійного і конструктивного їх обговорення та презентування перед широкою академічною громадою” як одному з цільових векторів сучасної реформи вищої освіти в Україні [4].

3. Стандарти і рекомендації щодо забезпечення якості в Європейському просторі вищої освіти (ESG). - K. : ТОВ “ЦС”, 2015. - 32 с.

4. Тематичний випуск “Європейська інтеграція вищої освіти України у контексті Болонського процесу” : теоретичний та науково-методичний часопис “Вища освіта України”. - К. : Інститут вищої освіти НАПН України, 2015. - С. 90. 